Berkeley Law

From the SelectedWorks of Robert Cooter

June, 1996

\title{
Comparative Judicial Discretion: An Empirical Test of Economic Models
}

Robert D. Cooter

Tom Ginsburg 


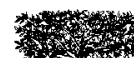

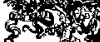 \\ Comparative Judicial Discretion: An Empirical Test of Economic Models
}

\author{
Robert D. CoOter AND Tom Ginsburg \\ Law School, University of California at Berkeley \\ E-mail:tomgee@uclink3.berkeley.edu
}

\section{The Problem of Discretion}

How much discretion do judges have in interpreting statutes? This is an important question for comparative constitutional law to consider. Comparative law scholars describe several factors that contribute to the relative amount of judicial discretion in a particular legal system. ${ }^{\prime}$ These factors include traditional conceptions of the proper role of judges, ${ }^{2}$ the structure of the judicial profession, ${ }^{3}$ and its degree of independence from political branches of government.

Taken on their own, these factors cannot explain why judicial activism and creativity vary across countries. The examples of the United Kingdom and the United States should serve to illustrate the point. Both countries share a common law tradition, prize judicial independence, and have a "status" (as opposed to civil service) judiciary. Both judiciaries are staunchly independent of their respective political systems. Yet American judges are usually considered far more adventurous than their British cousins. ${ }^{4}$

We approach this problem from the perspective of game theory. We think of judges as participating in a game of power against other officials. Judges have their own preferences about the political order. The court has a range of possible interpretations of any statutory language. The judges can satisfy their political preferences by exercising their power to interpret statutes. Judges are constrained, however, by the countervailing power of other officials. A judicial interpretation of a statute can be overturned by fresh legislation that explicitly stipulates the preferred interpretation of the legislators. The judges are constrained by the possibility of legislative repeal of their decisions, so the space of judicial discretion expands as overriding the court becomes more difficult. Game theory thus suggests the following prediction: Courts will be more adventurous in interpreting statutes when the prabability decreases of legislative repeal of their decisions.

An obvious way to test this theory may come to mind: When the preferences of court

The authors would like to thank Phil Spector, Keun Namkoong, Frans van Waarden, John Fleming, Dan Rubinfeld, and audiences at the American Law and Economics Association, the Institute of Governmental Studies at the University of California, and the Saarbruecken Conference on European Constitutional Law and Economics. 
and legislators diverge, legislatures should frequently enact fresh legislation to repeal the judicial interpretation of statutes. Research has discovered some illuminating examples that confirm this prediction. ${ }^{5}$ The relative frequency of legislative overrides of judicial decisions would appear to be a useful variable for the comparative analysis of judicial discretion. This obvious empirical test, however, is incomplete. To understand why, consider the analogy to bargaining games. The players in a bargaining game seldom carry out their threats, yet their relative power determines the terms of their cooperation. Similarly, judges seldom go so far as to provoke legislative repeal of interpretations, even though the possibility of repeal may determine how far the judges go in pursuing their own political preferences. When the political vision of judges conflicts with legislators, prudent judges pursue their own preferences to a point that stops short of provoking legislative repeal. Thus the relative power of officials controls their behavior, even though they seldom exercise their power against each other.

This paper approaches the relationship of judicial discretion to other branches in a different way. First we quantify two variables affecting the probability of legislative repeal of the judicial interpretation of statutes. One of these variables concerns the constitution and the other variable concerns political parties. Next we develop a series of indicators for how adventurous courts are in different countries. Finally, we regress the latter variables on the former variables. Part II of the paper explains the theory and Parts III through V test the model.

\section{A Modified Spatial Model: Legislative Resistance}

Constitutional law and economics has analyzed how the division of powers among the branches of government affects the discretionary power of courts. ${ }^{6}$ The theory predicts that a court's ability to diverge from legislative preference is a function of the number of independent vetoes on passing overriding legislation. Thus, a constitutional system like the American, which requires two independent houses of the legislature and the president to agree before a bill can become law, provides more room for judicial creativity than the British parliamentary system, wherein one house of parliament can pass most bills on its own. By imposing three independent vetoes on new legislation, the American system allows the court to diverge further before provoking a legislative correction.

The division of powers in the constitution provides one determinant of the probability that fresh legislation will repeal the judicial interpretation of a statute. This determinant is central to models in the existing literature. ${ }^{7}$ As conventionally stated, however, the model does not adequately reflect politics. The difficulty of the legislative process, which we call "legislative resistance," is also affected by politics. We believe that the underlying point of the model, namely that judicial discretion expands with the difficulty of passing legislation, to be a valid one, but politics is as important as the constitution.

One way politics determines legislative resistance is through political parties. The greater the degree of party discipline, the more party leadership can influence outcomes in a predictable way. Legislative systems with undisciplined parties may require more negotiation to form coalitions to enact legislation. The need for legislative bargaining to enact legislation may give courts more space to interpret statutes.

Besides party discipline, the number of member parties in the governing coalition and its stability affect resistance to legislation. If there are many political parties in the 
governing coalition, new legislation requires more extensive interparty negotiation than in a system where there is a single disciplined party. ${ }^{9}$ Again, this increases room for judicial action. By contrast, a single dominant party with discipline can easily impose its preferences upon the legislature.

The number of independent vetoes on fresh legislation provided in the constitution of a nation can be counted. Similarly, the stability of the governing coalition can be quantified. We will explain how we quantify these variables for purposes of our statistical analysis.

\section{Legislative Vetoes}

Narrowly interpreted, "legislative veto" refers to the formal power to veto legislation. Broadly interpreted, any body whose assent is required to create new law has a veto, because such a body may choose not to allow the legislation to proceed. We will describe the number of vetoes in various political systems, broadly interpreted. This description is stylized because certain kinds of exceptional legislation, like the budget, may require special procedures involving otherwise dormant upper houses. In some countries, such as Germany and Israel, legislation requires a presidential signature, but this is a ceremonial and not a real veto. Furthermore, in some countries the drafting of legislation is performed by the civil service, which may itself have an independent policy preference. For simplicity, these factors are not fully taken into account. Our model concerns only ordinary legislation and only counts vetoes that are regularly exercised.

The Constitution determines the number of legislative vetoes in a political system. In unicameral parliamentary systems, where the government is formed by the majority coalition in the legislature, there is essentially one veto on legislation. ${ }^{10}$ This describes the situation in the United Kingdom, Sweden, Israel, and Japan. ${ }^{11}$

Other systems have two vetoes on new legislation. Such would be the case in either a bicameral parliamentary system (as in Germany), ${ }^{12}$ or an essentially unicameral parliamentary system with a strong President (as in France).$^{13}$ Finally, as described above, the United States is exceptional in that it has three legislative vetoes: the two independent houses of the legislature and the President. The column labeled "Vetoes" records these facts in Table 1 .

\section{Dominant Disciplined Party and Coalition Duration}

The exercise of legislative vetoes depends on the party system. For example, if a single coalition holds both houses of parliament in a bicameral parliamentary system, the key determinants for whether a particular bill will be passed lie within that coalition. Bargaining will take place first within the governing coalition, and only later between the two houses of the legislature. The most important bargaining involves developing the proposal. $^{14}$

Several factors can minimize the salience of institutional vetoes. If parties are disciplined so that individual members seldom defect from bargains, party leadership can control the votes of backbenchers. This means that party leaders in a coalition can bargain on a given proposal with relative certainty that they will be able to deliver their votes. Once such a bargain is struck, it does not much matter how many legislative vetoes exist, as long as they are all controlled by the coalition. 
TABI.E. 1. Legislative resistance

\begin{tabular}{lcc}
\hline Country & Vetoes & $\begin{array}{c}\text { Avg. Coalition Duration } \\
\text { (in years) }\end{array}$ \\
\hline Australia & 2 & 9 \\
Austria & 2 & 8 \\
Belgium & 2 & 4.8 \\
Canada & 2 & 8 \\
Denmark & 1 & 8 \\
Finland & 2 & 4.8 \\
France & 2 & 6.8 \\
Germany & 2 & 6.3 \\
Ireland & 1 & 6.4 \\
Israel & 1 & 2.4 \\
Italy & 2 & 1.3 \\
Japan & 1 & 9.4 \\
Luxembourg & 2 & 4.4 \\
Netherlands & 2 & 2.5 \\
New Zealand & 1 & 6 \\
Norway & 1 & 4 \\
Spain & 1 & 6 \\
Sweden & 1 & 4.2 \\
United Kingdom & 1 & 8 \\
United States & 3 & 6.9 \\
\hline mean & 1.6 & 5.9 \\
\hline
\end{tabular}

Sources: F. Browne and J. Dreijmanis, eds., Gotemment Coa. titions in Western Democracies (1982); A. Lijphart, Democracies (1984); Keesing's Contemporary Archives; A. Blaustein, ed. Constilutions of the World.

If the governing coalition consists of a single disciplined party, bargaining over the proposed bill takes place entirely within that party. This is the case, for example, in the United Kingdom, which has well-disciplined parties and a unicameral legislature that is controlled for long periods by a single party. We characterize this situation as the Dominant Disciplined Party (DDP), because the position of the Party and its internal discipline mean that any proposal it wishes to impose on the country can be passed with relatively little resistance from the legislature.

There are several possible variables that might indicate the presence or absence of a DDP. Ideally we would like to have a measure of the ability of a party to impose its substantive preferences through the political process. One measure would be the success rate of party proposals. However, counting every instance where a party proposes legislation requires extensive information not easily available for comparative research. Furthermore, such a measure would miss those instances where a relatively weak ruling party wants to propose legislation but does not do so because it anticipates failure.

In a parliamentary system, where the government serves at the pleasure of the legislature, the average duration of the cabinet is one possible indicator of party dominance. As long as the governing coalition commands the support of the parliament, the cabinet continues in office. When the parliament withdraws its support (for example, by reject- 
ing an important government bill) the government falls. A DDP should be able to maintain cabinets for longer than weaker parties.

Cabinet duration, however, is affected by constitutional rules about elections as well as by the party system. This is because elections mandate a formal change in government even if the ruling party stays in power, and all democratic constitutions provide for a maximum duration between parliamentary elections. Thus a dominant party in a system that requires elections at least every 5 years will have longer cabinets than an equally dominant party in a system with triennial elections.

A simpler indicator of party dominance is coalition duration. A dominant party will be able to hold power through multiple elections. An extreme example is the Liberal Democratic Party of Japan, which formed 14 consecutive governments and ruled from its formation in 1955 until 1993. Similarly, the United Kingdom has been ruled by disciplined Conservatives for a decade and a half. Systems where party discipline is low or where no dominant party holds sway will tend to have shorter coalitions.

We counted the number of changes in the party composition of the governing coalition for each of twenty countries and then divided by the number of years to determine the average coalition duration. ${ }^{15}$ For most countries the period of study was 1945 to 1993 , but in certain cases we adjusted the period to reflect constitutional change. Thus in France, we began with the founding of the Fifth Republic in 1958. In Germany, we began with the founding of the Federal Republic in 1949. The details are given in the Appendix.

One theoretical problem comes in applying this indicator to countries such as the United States with a Presidential system or countries like France with a mixed system. In both cases, there is the possibility of divided government wherein one party controls the legislature and another the presidency. For example, from 1981 until the most recent elections in 1995, France has enjoyed mainly socialist rule under a socialist President with brief periods of Gaullist government. In the United States, divided government is the norm. ${ }^{16}$ We used the party composition of the cabinet as the indicator for both kinds of systems. Thus in the United States, the composition of the cabinet changes whenever there is a change in the party controlling the Presidency. In France, the Prime Minister is typically drawn from the majority coalition in the legislature, so control over the legislature becomes the basic indicator of coalition duration.

Some countries have political systems wherein one party is at the center of coalitions but must rely on smaller parties to govern. We believe our coalition duration variable captures the relative stability of these systems. For example, the Christian Democrats have been at the center of almost every postwar Italian government, much as the Social Democrats have been in Sweden. The Christian Democrats have been unable to form stable coalitions, however, and have had to adjust the composition of the cabinet almost annually since World War II.

According to our hypothesis, longer coalitions would tend to correlate negatively with legislative resistance. This is because longer coalitions indicate a government's ability to maintain discipline and enact its legislative program. The average cabinet duration for twenty countries is presented in Table 1.

Table 1 predicts that judicial discretion is lowest in those countries with a low number of vetoes and a high average coalition duration, such as Japan and the United Kingdom. Judicial discretion will be highest in countries with either a large number of vetoes, such as the United States, or low average cabinet duration, such as Italy and Israel. Other countries in the middle include Germany and France. 
The next sections of the paper test this prediction. The first test consists of a simple questionnaire of experts. The second consists of a study of one area of law that has been especially suited to judicial daring, namely, the move to strict liability for tort claims dealing with defective products. The final test concerns the pattern of environmental regulation in various legal systems.

\section{Test One: Experts Views}

As a first test, we asked a small number of comparative law scholars for their views on the degree of judicial daring in the various countries. The questionnaire asked experts to rate the adventurousness of courts in different countries on a five-point scale. For example, one expert assigned the U.S. courts a 5 to indicate that they were the most daring, courts in the United Kingdom a 1, and German and French courts a 3. The various experts' ratings were then averaged so that each country had a single number. Table 2 shows the average ratings for each country.

Table 3 shows the results of regressing the expert ratings on the two variables in Table 1. The explanatory variables have the predicted signs. Both variables are significant at the $5 \%$ level. The two variables explained over $50 \%$ of the variation.

To illustrate these results, an increase of one veto in a constitutional system would move the courts .79 units on our five-point scale, equivalent to the move from the position of German courts 10 the position of the allegedly more adventurous Dutch courts, or from the position of French courts to the position of American courts. Similarly, a 1-year increase in average coalition duration would lower a country 17 units, or from the position of the Canadian courts to that of the less adventurous Japanese courts. A 2-year decrease in average coalition duration would increase the courts adventurousness from the level of Dutch courts to those of the United States.

TAнı. 2. Expent ratings of judicial daring

\begin{tabular}{lcc}
\hline & Average fredicion & Standard drviation \\
\hline Israel & 4.50 & .58 \\
United States & 4.42 & .67 \\
Netherlands & 4.20 & .50 \\
France & 3.70 & 1.06 \\
Belgium & 3.50 & .58 \\
Germany & 3.46 & .93 \\
Italy & 3.33 & .82 \\
Sweden & 2.50 & .58 \\
Australia & 2.33 & .58 \\
Cianada & 2.33 & .58 \\
Japan & 2.17 & .98 \\
United Kingdom & 2.10 & .99 \\
Spain & 2.00 & 1.00 \\
New Zcaland & 2.00 & 1.00 \\
\hline mean & 3.04 & \\
\hline
\end{tabular}

Only countrics for which three or more responses were gathered are included. 
TABLE 3. Expert ratings of judicial daring regressed on two determinants of legislative resistance

\begin{tabular}{lcccc}
\hline variable & coefficient & sid. error & t-stat. & 2-tail sig. \\
\hline constant & 2.74 & 0.69 & 3.06 & 0.01 \\
Vetoes & 0.86 & 0.31 & 2.80 & 0.02 \\
Coalition & -0.17 & 0.07 & -2.35 & 0.04 \\
Duration & & & & \\
\hline
\end{tabular}

R-squared $=0.55 ;$ Prob $($ F-statistic $)=0.014 ; \mathrm{N}=14$.

\section{Test Two: The Move to Strict Liability}

To test further our prediction of judicial daring, we examined one area of law as a case study: the adoption of strict liability for consumer product injuries. We found that courts with high predicted daring were willing to innovate in this area of private law more than other courts. Courts with low predicted daring, by contrast, were content to wait for legislative adoption of the new standard.

Before the move to strict liability for product defects, liability had usually been based on traditional standards of negligence in tort doctrine. Traditional doctrine required the plaintiff to prove that the defendant's negligence caused the sale of a defective product. Alternatively, many jurisdictions had a contract law doctrine that allowed buyers to sue sellers for breach of contract (sometimes using an "implied term" or warrant of merchantability). Contract iiability was strict, but when narrowly construed the doctrine had limited utility in product liability cases. For example, contract liability is usually restricted to the actual seller of the product, so it does not extend easily back to the manufacturer.

As the number and type of consumer products have expanded with the modern economy, most wealthy countries have moved to strict liability for injuries caused by defective products. (A large debate concerns whether this change increases or decreases economic efficiency. ${ }^{17}$ )

The key question for our model is whether the jurisdiction adopted strict liability through judicial or legislative mechanisms. We hypothesize that more daring courts would sooner overturn a traditional tort law standard than would more conservative courts. Conservative courts may be more likely to defer the strict terms of legislative doctrine.

The first jurisdiction to move to a strict liability standard was California, and some form of its rule was adopted by all U.S. jurisdictions. ${ }^{18}$ The first European jurisdiction to move to a strict liability standard for product liability claims was France. Product liability claims were traditionally based on either contract or tort provisions in the French code. The Cour de Cassation gradually unified the remedies available to consumers. ${ }^{19}$ While the French system of consumer protection is extremely complicated, the main point is that in the United States and France courts led the way in changing liability law.

There are three possible ways in which strict liability could be adopted. In some jurisdictions, as described above, courts moved to a strict liability standard before the legislature mandated it, overturning traditional doctrine (and sometimes the explicit text of the codes). This was the case in France and the United States. ${ }^{20}$ In other 
countries, such as Germany, Italy, and Israel, courts went part of the way by reversing the burden of proof. Under traditional law in product liability cases, the plaintiff must prove that the defendant was negligent, whereas under revised law the defendant must prove that he was not negligent. Reversing the burden of proof helps plaintiffs overcome evidentiary problems and thereby significantly expands liability for manufacturers. Finally, certain courts neither moved to strict liability nor reversed the burden of proof, and the move to strict liability was initiated by the legislature (as in the United Kingdom, Sweden, and Japan).

These facts provide a basis for quantifying judicial daring in the area of consumer products liability (Table 4). Countries where courts moved to strict liability without legislative construction are assigned a 3 . Countries where courts went partway, a lesser but still significant judicial innovation, are assigned a 2 . Finally, courts that refused to innovate are assigned a 1 .

Table 5 shows what happens when we use a multivariate statistical procedure to explain these results with our two variables indicating legislative resistance. Because the dependent variable in the equation represents an ordinal rather than a continuous variable, we apply an ordered probit model to estimate the equation.

The results of the equation in Table 5 are similar to the results in Table 3 using ordinary least squares. Specifically, the two explanatory variables have the predicted

TABIF. 4. Judicial role in developing strict liability (SL)

\begin{tabular}{lccc}
\hline Country & $\begin{array}{c}\text { Judicial role } \\
\text { in } S \text { N }^{*}\end{array}$ & Vetoes & Coatition Duration \\
\hline Australia & 1 & 2 & 9 \\
Austria & 2 & 2 & 4.8 \\
Belgium & 3 & 2 & 4.8 \\
Canada & 2 & 2 & 8 \\
Denmark & 1 & 1 & 8 \\
Finland & 1 & 2 & 4.8 \\
France & 3 & 2 & 6.8 \\
Germany & 2 & 2 & 6.3 \\
Ireland & 1 & 1 & 6.4 \\
Israel & 2 & 1 & 2.4 \\
Italy & 2 & 2 & 1.3 \\
Japan & 1 & 1 & 9.4 \\
Luxembourg & 3 & 2 & 4.4 \\
Netherlands & 2 & 2 & 2.5 \\
New Zcaland & 1 & 1 & 6 \\
Norway & 1 & 1 & 4 \\
Spain & 1 & 1 & 6 \\
Sweden & 1 & 1 & 4.2 \\
United Kingdom & 1 & 1 & 8 \\
United States & 3 & 3 & 6.9 \\
\hline
\end{tabular}

$* 3=$ Judicial move to strict liability; $* 2$ Cts. reverse burden; *1 leg. adopts SL. Sources: W. Freedman, Product Liability: An Intermational Manual of Practice (1990); P. Kelly and R. Attree, European Produrt Liability (1992); G. Howells, Comparative Product Liahlity (1993); A. Mottur "European Product Liability", Law and Policy in Intermational Business (1994). 
TABI.F. 5. Ordered probit model relating consumer products liability to two determinants of legislative resistance

\begin{tabular}{lccrr}
\hline variable & coefficient & sid. error & z-stat. & $P>z$ \\
\hline Vetoes & 2.28 & 0.73 & 3.15 & 0.002 \\
Coalition & -0.20 & 0.13 & -1.36 & 0.172 \\
Duration & & & & \\
\hline
\end{tabular}

pseudo R-squared $=0.40 ; \mathrm{chi}^{2}=16,12 ;$ Prob $>\operatorname{chi}^{2}=0.0003 ;$ Log likelihood $=$ $-12.531 ; \mathrm{N}=20$.

sign, Vetoes is highly significant, and Cabinet Duration is marginally significant as well. The equation explains $40 \%$ of the variation in the dependent variable.

The data in Table 4 is simplified, so we provide more detail on some of the larger countries. The European jurisdictions are complicated by European Union (EU) intervention into accident law. On July 25, 1985, the European Council issued a Directive on Products Liability. ${ }^{21}$ Directives are essentially orders to member country legislatures to upgrade their domestic laws in a particular area. Following a directive, each country's legislature must act to bring the legal system in to compliance. Directives use the method of "approximation," wherein they specify a range of outcomes within which national regulation may fall.

The objective of the Products Liability Directive was to unify law within the Common Market related to defective products, which had historically been quite different across legal systems. The Community felt that the varying levels of consumer protection would act as a barrier to free trade within the community.

What were the effects of the Community Directive on member countries' legal systems? Although the Directive was "a welcome opportunity to harmonize and simplify existing law" for France, ${ }^{22}$ the Parliament has not yet passed legislation to implement the directive. The European Commission issued a warning to France in the regard in 1990, and apparently there is a pending lawsuit to force the French to comply with the Directive. Given that the Directive is not as strict in some areas as existing French law, ${ }^{23}$ the legislative reluctance is puzzling

Before the issuance of the directive, Germany did not have strict liability, but rather based product liability damages on traditional contract and tort doctrines. ${ }^{24}$ Whether found in contract or tort doctrine, remedies have been comparable, although subject to technical differences. ${ }^{25}$ German courts reversed the burden of proof from the plaintiff so as to substantially protect the consumer from defective products. ${ }^{26}$ The result is much like strict liability for practical purposes, but still the courts were reluctant to directly challenge the legislature.

After the Directive, Germany passed a Product Liability Act, ${ }^{27}$ which introduced the strict liability standard and provided relief for certain classes of cases not previously covered by judicially created doctrine. With its emphasis on consumer protection, the European Directive called for less liability for products used for business/professional use, so old tort-based doctrine will continue to be important in this ares. ${ }^{28}$ The Directive did not much change German law for practical purposes, as evidenced in part by the fact that product liability insurers did not raise their rates after the new legislation entered into force in $1990 .^{29}$

In Italy the Directive was implemented by governmental decree. ${ }^{30}$ Like the German 
implementing legislation, it does not exclude other causes of action, so previously valid tort rules still apply. Again, similarly to Germany, the traditional tort doctrine burden of proof had already been reversed by courts with regard to negligence in product liability cases. ${ }^{31}$ Contract claims are also allowed for financial damages. The Directive did introduce some changes into Italian law, including "the concept of willing assumption of risk which is different from the contributory negligence hitherto known in Italy." "32 As in Germany, contributory negligence of the plaintiff still provides a defense.

Traditionally, product liability in Sweden had been covered by tort and contract doctrines as well as a Consumer Safety Act. Where contract and tort doctrines are applicable, the burden of proof rests with the plaintiff, but court practice has somewhat diminished the standards of evidence. ${ }^{33}$ Nevertheless, there was in no sense a judicially mandated move to strict liability, nor was there the general reversal of the burden of proof found in Germany. ${ }^{34}$ Of special importance in Sweden are legislatively created social insurance programs, which protect consumers as would a regime of strict liability in many cases. ${ }^{35}$ Courts had little incentive to impose strict liability in such a context. After many years of discussion, a Products Liability Act was passed in 1992, substantially conforming with the Community Directive. (Even before becoming an EU member, the Swedish legal authorities sought to harmonize national rules with Community law.)

Before the Directive, the United Kingdom system was characterized by a multiplicity of laws under which product liability claims may be lodged. These include standard tort and contract doctrine, and a number of pieces of legislation. The statutory scheme is complicated, but the important point is that before 1987 , liability was not strict. Judicial tests of remoteness and the doctrine of contractual privity limited damages in many cases. Much changed with the Consumer Protection Act of 1987, which consolidated existing legislation as well as implemented the Community Directive, moving to a strict liability standard for most cases. The U.K. Act diverged from the Directive in the area of development risks, and has proved controversial. ${ }^{36}$ But the United Kingdom was the first country to pass implementing legislation after the directive, illustrating our contention that legislative resistance is low in the United Kingdom.

The above descriptions cover selected European countries, but the other countries in our study show similar patterns. Israel's law had been derived from the United Kingdom's traditional reliance on fault as the source of tort liability. But, as in Germany, the courts had shifted the burden of proof from plaintiff to defendant because of the evidentiary difficulties plaintiffs would face. In 1980, the Knesset passed a Defective Products Liability Law, imposing strict liability. ${ }^{37}$

In Japan, the move to strict liability was long delayed, the first statute not emerging until June 1994. ${ }^{38}$ Although product liability reform received extensive discussion by both scholars and judges for many years, the legislature resisted a change and the courts were not powerful enough to mandate the switch on their own. The resistance of the legislature has been said to reflect industry strength, but the judicial reluctance to move reflects a conservatism that is extraordinary among industrial democracies. ${ }^{39}$

Of the countries in our study, only France, Belgium, Luxembourg, and the United States had judicially created strict product liability. The other countries moved legislatively to strict liability, although courts in Germany, Italy, Israel, and other countries had gone partway by reversing the burden of proof. Japanese, U.K., and Swedish courts had not reversed the burden. The 10 countries from our sample that fell into the latter group had, on average, less vetoes and longer cabinet duration than the 10 in the other 2 groups. ${ }^{40}$ 


\section{Test Three: Pollution Regulation}

Judicial innovation in private law is one indicator of discretion. We believe that the logic of judicial discretion operates in public law as well, and in this section we extend our argument to another area of legal change, specifically pollution regulation. The argument here is more complex. We argue that countries with greater legislative resistance are more likely to judicialize public policy tasks and are also likely to write detailed statutes to try to constrain courts with otherwise broad discretion.

Public law complicates the model because of the continental tradition of separate administrative courts. ${ }^{41}$ Administrative courts are different because the judges tend to be tangled in administration and not independent of it. For simplicity, our discussion concentrates on countries with unified court systems, where courts of general jurisdiction here disputes on administrative matters. This group includes Japan, the United States, and the United Kingdom.

Let us consider why politicians in some countries might prefer independent courts. Politicians need the power to commit themselves to policies. The power to commit enables politicians to bargain with others and strike mutually beneficial deals. In general, commitment can occur in two ways. One way is for a disciplined party with enduring control over government to develop a reputation for keeping promises. Having invested in reputation, the party can guarantee its promises by backing them with its valuable reputation. Under such conditions, independent courts only hinder political action. ${ }^{42}$ This method of commitment, however, is unavailable to governments without an enduring, disciplined, and dominant party. Short-lived coalition governments need another way to make commitments.

The other way is to create independent courts with the authority to interpret bargains embodied in laws. Courts serve as agents of enacting coalitions by insulating policies from reversal after electoral losses. ${ }^{4.3}$

Governments run by a DDP can make commitments without independent courts, whereas other governments may need independent courts to make credible commitments. Thus, J. Mark Ramseyer argues that ruling politicians will prefer independent courts where they believe (a) there is a high likelihood of continuing elections, and (b) they are not likely to continue winning the elections. ${ }^{44}$ Ramseyer only illustrates the argument with evidence from America and Japan. Generalizing, we conclude that Dominant Disciplined Parties are unlikely to prefer independent courts to protect their policies. Furthermore, they are likely to avoid judicializing new policy areas because courts could deny the politicians the flexibility needed for political bargaining with various actors. We predict less "judicialization" of public policy in countries with a strong DDP.

One indicator of judicialization is statute length. When governments are confident in their ability to informally control courts and agencies, there is little need to write detailed and precise statues. Where they are not so confident, they will want to write detailed statues so they can use courts to monitor agencies.

The case of pollution regulation in the United States, Japan, and the United Kingdom illustrates this point. Table 6 presents data on the length of air and water pollution control statutes in these countries.

It is clear that, even from our crude estimates, U.S. statutes are of an order of magnitude more lengthy (and by extension more specific) than similar laws in the other jurisdictions. While this may not establish a causal relationship between legislative re- 
TABIE 6. Length of pollution control statutes (est. words) ${ }^{45}$

\begin{tabular}{|c|c|c|c|}
\hline & Japan* & $U K$ & US \\
\hline Air Pollution Statute ${ }^{4 t i}$ & 12,675 & 62,475 & 544,980 \\
\hline Air Pollution Regulations & 116,025 & 46,980 & 729,120 \\
\hline Water Pollution Statute & 42,900 & 29,400 & 240,560 \\
\hline Water Pollution & 189,150 & 29,970 & 854,980 \\
\hline \multicolumn{4}{|l|}{ Regulations } \\
\hline TOTAL $^{47}$ & 360,750 & 168,825 & $2,379,640$ \\
\hline
\end{tabular}

sistance and judicial discretion, it does provide one more piece of evidence consistent with our prediction.

We now provide more detail on the pattern of pollution regulation in our three countries. In Japan, high-growth policies created significant pollution problems by the end of the $1960 \mathrm{~s} .{ }^{48}$ After severely damaged children were born at Minamata, plaintiffs sued polluting companies in tort and won in the so-called "big four" cases. Faced with a new public policy problem, the bureaucracy intervened and drafted a statute with a mediation and compensation scheme for future cases. The bureaucracy thus usurped the process of pollution compensation from the courts. American style environmental legislation was adopted with environmental impact assessments and public hearing process, but with important modifications that minimized the impact of either innovation. The Japanese version of the Environmental Impact Assessment, for example, was unenforceable in court, and participation in public hearings was structured by the bureaucracy, which tended to give voice only to local interests. In general, Japanese administrative law severely limits access to the courts, as one might expect in a system with little legislative resistance. In sum, although courts attempted to innovate by holding industry liable, pollution compensation was quickly removed from courts. Pollution control schemes were developed through bureaucratic consultation and discussion with industry, rather than through legal challenge.

Environmental regulation in the United Kingdom follows a similar pattern of utilizing informal discussions between regulators and businesses, not courts. ${ }^{49}$ Environmental statutes are broadly written and provide administrative flexibility in implementation so that the particular circumstances of each polluter and community can be met. This flexibility is captured in the statutory requirement that cleanup efforts must use the "best practicable means" with sensitivity to cost, capacity of the environment to absorb pollution, and pace of modification. Standards are met through voluntary compliance far more than government prosecutions. Political control is ensured through the Secretary of the Environment, who can hear appeals of the pollution control agency decisions.

In the United States, by contrast, statutes are written with strict detail. The Clean Air Act of 1970 is a good example. Pollution cleanup efforts are required to use the "best available technology" regardless of costs or environmental necessity, and sometimes regulations are "technology forcing." "50" Citizens have the right to sue the administering agency, the Environmental Protection Agency (EPA), and the EPA itself may sue polluters. Access to courts allows citizens to sue, but judicial solutions often allow polluters to delay compliance efforts. ${ }^{51}$

Extending the analysis to other countries shows a similar pattern to the tort area 
discussed above. In France, environmental liabilities arise out of general civil and criminal codes, which are judicially interpreted. The law of industrial nuisance, for example, was judicially rather than legislatively created. Legislation has come only later. A new environmental code is in draft form but has not yet been passed. So judges have had more of a say in this area than their counterparts in other countries. By contrast, the Swedish legislature has been very active, with more than 260 relevant acts and ordinances as of $1987 .{ }^{52}$ As in the English case, Swedish agencies are required to balance several competing interests in a flexible manner.

The example of environmental regulation shows that judicial discretion may be minimized simply by the legislature choosing not to judicialize a policy area. Courts cannot exercise discretion in cases that are not brought before them. Where a DDP holds sway, as in the United Kingdom, Japan, and Sweden, judges will not be as involved in implementing pollution regulation. In contrast, where power is divided and split, independent courts may be created so that policy decisions can be legalized and maintained after the enacting coalition has faded away. Detailed statutes are need both to control courts and to empower courts to monitor bureaucratic agencies.

\section{Omitted Variables}

We should mention two variables not taken into account in our model. The first is the material independence of the courts from the political process. Where judges are dependent on politicians for their budget, promotions, and other assignments, they are likely to decide cases in accordance with the wishes of the politicians who control their purse strings. We do not include this variable, because we believe it may be congruent with our measure of DDP. Dominant parties can easily impose their preferences on judges, because judges know that the party is likely to continue to be in power and that there is little to be gained from defying it. Where parties alternate in power, any attempt to coerce the judiciary through manipulation of material incentives will likely provoke the other political parties to do the same. It is therefore in neither party's interest to begin to politicize the judiciary. Furthermore, without a DDP, individual judges may resist such attempts, since they know that eventually the other party will "rescue" them from the imposition of a particular political viewpoint. Where a DDP holds power for a long period, judges are likely to be shaped during formative periods of their careers in directions consistent with DDP views. Finally, a DDP will gain a sophisticated understanding of mechanisms to control judges through long experience. For these reasons, material dependence on politicians is more salient when there is a DDP than where there is not.

The second omitted variable concerns the bureaucracy. In many systems it is the bureaucracy and not the legislature that actually drafts laws. The administration might be argued to constitute another legislative veto. But the bureaucracy also can veto judicial decisions in other ways, for example, by failing to enforce judgments or judicial orders. For simplicity, we leave the bureaucracy out of the model and assume that it acts as an agent of the legislature.

Clearly, judicial discretion is difficult to measure. In some areas of the law where the legislature has been inactive, the courts have moved away from old, out-of-date rules without specific instruction from the legislature. Nevertheless, this does not mean that the sitting legislature has a different policy preference from that of the courts. Rather 
it might mean that the legislature does not have a strong preference, or that it prefers to leave innovation to judicial authorities.

Another problem is the difficulty of comparing legal systems. In most every country, whether a recipient of the common law or continental tradition, judges do make law. While this is explicitly acknowledged and even celebrated in the common law, civil law tradition is more suspicious of judicial creativity. In the civil law system, lawmaking is allegedly the function of the legislature, and law-applying is the function of courts.

This difference in conception mirrors deeper difficulties around what constitutes discretion. Is a court that invents a standard where none previously existed exercising greater discretion than another court that expressly contradicts an outmoded legislative provision? Might a court acting to create law in a civil law system where such functions are formally denied be more daring than a common law court adopting the same standard? In countries where courts' primary job is to interpret generalized codes, judges often must invent new standards to keep up with changing socioeconomic conditions. Is such judicial innovation greater when the code is older (under a theory that courts are tinkering with a more established tradition), or where the legislature has spoken more recently (in which case the court might be said to show greater defiance)? What about cases where judges have discretion but do not use it to create new law because their policy preferences are congruent with the legislature? These and other issues illustrate the comparative difficulties involved in discussing discretion in crossnational terms.

\section{Conclusion}

We have argued that the presence of a DDP limits judicial discretion and therefore limits judicial daring. Conversely, judicial daring expands as the number of vetoes on fresh legislation increases. We have demonstrated that experts' subjective perceptions of judicial daring correspond to our predictions. ${ }^{53}$ Next, we showed that the pattern of countries' adoption of new standards of producer's liability in tort reflected our predictions for how daring courts would be. Finally, we have argued that countries with a DDP tend to have less judicial control over public law, as shown by the example of pollution control.

We close with some predictions for the future. Political scientists have noted a decrease in party discipline in Europe in recent years, the causes of which are mysterious. As party discipline declines, legislative resistance (holding constitutional vetoes constant) and the discretionary power of courts increases. We therefore predict that if party discipline continues to decline, it will be accompanied by an increase in judicial daring.

Another factor that increases judicial daring is the introduction of more vetoes. For example, recent Israeli amendments to the Basic Law provide for direct election of the Prime Minister in that country beginning in 1996. This may increase the number of real vetoes from one to two, and this should increase the scope for judicial activism there unless other changes in Israel lower legislative resistance by producing fewer parties with more discipline.

Our model also has implications for the future of the EU. We expect that as legislative resistance increases, the power of the European Court of Justice expands. The development of the EU has brought an increase in the power of the European Parliament. 
While primary legislative powers still belong to the Council, the strengthening of the Parliament is a move towards bicameralism. This change increases legislative resistance, which should expand the judicial discretion in the European Court of Justice. ${ }^{54}$

Appendix

Coalition Duration

\begin{tabular}{|c|c|c|c|c|c|}
\hline Couniny & Start Year & End Year & Total Years & $\begin{array}{l}\text { Number of } \\
\text { Coalitions }^{56}\end{array}$ & $\begin{array}{c}\text { Average Duration } \\
\text { (years) }\end{array}$ \\
\hline Australia & 1958 & 1994 & 36 & 4 & 9 \\
\hline Austria & 1945 & 1993 & 48 & 10 & 4.8 \\
\hline Belgium & 1945 & 1993 & 48 & 10 & 4.8 \\
\hline Canada & 1945 & 1993 & 48 & 6 & 8 \\
\hline Denmark & 1945 & 1993 & 48 & 6 & 8 \\
\hline Finland & 1945 & 1993 & 48 & 10 & 4.8 \\
\hline France & 1958 & 1992 & 34 & 5 & 6.8 \\
\hline Germany & 1949 & 1993 & 44 & 7 & 6.3 \\
\hline Ireland & 1948 & 1993 & 45 & 7 & 6.4 \\
\hline Isracl & 1948 & 1993 & 45 & 19 & 2.4 \\
\hline Italy $y^{57}$ & 1948 & 1993 & 45 & 34 & 1.3 \\
\hline Japan & 1946 & 1993 & 47 & 5 & 9.4 \\
\hline Luxembourg & 1958 & 1993 & 35 & 8 & 4.4 \\
\hline Netherlands & 1945 & 1993 & 48 & 19 & 2.5 \\
\hline New Zealand & 1945 & 1993 & 48 & 8 & 6 \\
\hline Norway & 1957 & 1993 & 36 & 9 & 4 \\
\hline Spain & 1976 & 1994 & 18 & 3 & 6 \\
\hline Sweden & 1951 & 1993 & 42 & 10 & 4.2 \\
\hline United Kingdom & 1945 & 1993 & 48 & 6 & 8 \\
\hline United States $^{5 x}$ & 1945 & 1993 & 48 & 7 & 6.9 \\
\hline
\end{tabular}

\section{Notes}

1. See, e.g., M. Capelletti, 1989, The Judicial Process in Comparative Perspective, Oxford: Clarendon. For a theoretical account by the Chief Justice of Israel, see Aharon Barak, 1989, Judicial Discretion, Cambridge, MA: Harvard University Press.

2. In the common law tradition, judges may have a legitimate role in the creation of norms. This is less true in the continental or civil law tradition, where judges are urged to apply legislatively created norms.

3. A key variable here is whether the judiciary is organized along the lines of a hierarchical civil service model, in which judges enter the profession at a relatively young age and advance through adhercnce to internally maintained professional norms. In the common law tradition, entry to the judiciary is a prestigious appointment that comes at the end of a distinguished legal career. Advancement is less of a concern, and the upper echelons of the profession have fewer collateral means of controlling the incentives of lower-court judges (though they do maintain control over legal norms through the appeals process).

4. See, e.g., Kenneth Holland, Ed. 1991, Judicial Activism in Comparative Perspective, New York: St. Martin's.

5. The model is developed in Gely and Spiller, "A Rational Choice Theory of Supreme Court Statutory Decisions with Applications to the State Farm and Crove City Cases," 6 Journal of Law, Economics and 
Organization 263 (1990). For a discussion of the U.S. Congress correcting judicial interpretation of civil rights legislation, see Abner Mikva and Jeffrey Bleich, "When Congress Overrules the Court," 79 California Law Review 729 (1991).

6. Our research draws upon similar models developed for the United States in J. Ferejohn and B. Weingast, "A Positive Theory of Statutory Interpretation," 12 Intemational Reviow of Law and Eornomics, 263-279 (1992); J. Ferejohn and B. Weingast, "Limitation of Statues: Strategic Statutory Interpretation," 80 Geongetoun Law Journal 565-582 (1992); and W. Eskridge, "Overriding Supreme Court Statutory Interpretation Decisions," 101 Yale Law Joumal 331 (1991). For the same model with an administrative agency, see B. Weingast and M. Moran, "Bureaucrats ws. Voters: On the Political Economy of Resource Allocation," 93 Quarterly Joumal of Economics 143 (1979); J. Ferejohn and C. Shipan, "Congressional Influence on Bureaucracy," 6 Joumal of Law, Economics, and Organization, 1-20 (1990); M. Spitzer, "Extensions of Ferejohn and Shipan's Model of Administrative Agency Behavior," 6 foumal of Law, Economics and Organization. 29-43 (1990); S. Rose-Ackerman, "Comment on Ferejohn and Shipan's 'Congressional Influence on Bureaucracy,' "6 Joumal of Law, Economics, and Organization, 21-27 (1990).

7. For an empirical study of American court decisions based on the model, see Spiller and Gely, "Congressional Control of Judicial Independence: The Determinants of U.S. Supreme Court Labor-Relations Decisions, 1949-1988," 23 Rand Joumal of Eonomics 463 (1992). The framework is developed in Gely and Spiller, supra note 5.

8. Note that it could also mean that courts have less information about stable legislative preferences, which may lead the court to be cautious for fear of overreaching. Alternatively, courts may underestimate legislative concern, in which case their imovation could provoke legislative correction because of the uncertaincy of legislative preferences. Current demands for tort reform in the United States may reflect such dissatisfaction with judicial innovation.

9. The structurc of the party system itself is heavily influenced by electoral laws. For an empirical study, see R. Taagepera and M. Shugart, 1989, Seals and Votes: The Effects and Determinants of Electoral Systems, New Haven, CT: Yale Lniversity Press. Also see B. Grofman and A. Lijphardt, 1986, Electoral Lazes and Their Political Consequences Edison, NJ: Agathon.

10. This is the case whether proposals for new legislation originate in the government or the legislature.

11. Note that in both Japan and England there is an upper house of parliament, but its assent is only required for the budget and not for most ordinary legislation. Israel recently modified its Basic 1 . aw so that beginning in 1996 the Prime Minister will be directly elected rather than simply the head of the leading party in the parliamentary coatition. This has increased the number of legislative vetoes to two.

12. Technically the Bundesrat is not an upper house but a distinct institution. However, it can impose an absolute veto on any legislation affecting the lander. See Arthur Gunlicks, "German Federalism After Unification: the Iegal/Constitutional Response," 24 Publius 81, 84 (1994). Since such legislation constitutes well over $50 \%$ of the total, we treat the German system as bicameral. Although the Chancellor and President must also sign legislation, the President's signature is ceremonial and the Chancellor's veto is not exercised independently of the parliamentary majority.

13. The French system is formally bicameral, but in fact the Scnate is indirectly elected and can only delay lower house legislation and not block it. While this has the effect of imposing additional transaction costs and thereby increasing legislative resistance, for simplicity such partial veloes are not counted in our model.

14. Nelson Polsby characterizes these kind of legislatures as arenas, in contrast with transformative legislatures, which regularly modify the legislation in substantial ways. See Polsby, 1975, "Lcgislatures," in F. Greenstcin and N. Polsby, Eds., Encyclopedia of Political Science, Vol. 1, Redding, MA: Addison Wesley.

15. For purposes of this paper, changes in composition occur only when a party is added or dropped from the coalition, and not when the cabinet seats are merely reshuffled among existing coalition members. Nor is there a change when the same coalition continues in power after new elections. 
16. Gary Jacobson, 1990, The Electoral Origins of Divided Government, Boulder, CO: Westview.

17. See discussion in R. Cooter and T. Ulen, 1988, Law and Fronomics, Glenview, IL: Scott Foresman, 421-462; and S. Shavell, 1987, Economic Analysis of Acciden Law, Cambridge, MA; Harvard University Press. George Priest argues that the use of tort rather than contract doctrine in products liability cases is inefficient, Priest, "The Invention of Enterprise Liability: A Critical History of the Intellectual Foundations of Modern Tort Law," 14 Journal of Legal Studies 461 (1985). W. I andes and R. Posner take a slightly different view in "A Positive Economic Analysis of Products Liability," 14 Joumal of Legal Siudies 529 (1985).

18. The standard was first proposed by Justice Traynor in his concurrence in Escola v. Coca-Cola Bottling Co. 24 Cal. 2d 453 (1944). The rule did not become law in California until almost twenty years later, but thereafter it rapidly spread to other states.

19. See Article 1641 of the Civil Code, which provides that the seller is liable in respect of hidden defects that render the product unsuitable for its intended use.

20. The strict liability standard is a feature of state, not federal, law in the United States. This is a minor but not unsurmountable problem for our model, since our assessments of DDP and vetoes in the various countries were made at the national level. We believe that the constitutional framework of most states is consistent with the federal scheme, since all states but Nebraska have bicameral legislatures. Furthermore, fragmented national parties may be replicated at the state level.

21. Council Directive $85 / 374 / \mathrm{EC}$.

22. P. Kelly and R. Attrec, 1992, European Products Liability, London: Butterworths, p. 103.

23. For example, in that the seller of a defective product can be held jointly liable with the producer vis-a-vis hidden defects in the product. This principle derives from the contract law origins of product liability in France.

24. The Civil Code (BGB) of 1896 dealt in only a general way with contract law. There was a separation of warranty doctrine, which dealt with a consumers' interest in a properly functioning product and the problem of damages to health or property resulting from a defective product.

25. For example, in tort product requirements are standardized, whereas in contract breach cases they must be determined with regard to the specific contract. The seller's duties to inform the buyer are stricter in contract cases. Damages from pure financial loss are not recoverable in tort but only under breach of contract actions. Sec Kelly and Attree, supra note 22, pp. 132, 138. In contract, the defendant must prove that he was not at fault. Tort claims are more often used.

26. According to a 1988 decision (BGH in NJW 1988, $2611 \mathrm{ff}$ "Mehrwegflasche II") the burden of proof depends on several factors: whether there has been a defect that affects the claimant's right, whether the defect results from the production process, and whether there has been a negligent or intentional disregard of due care related to the defect. The defendant must exonerate himself from liability from fault for matters related to internal production, and "in practice, this exoneration almost never succeeds." Kelly and Attree, supra note 22, at 147.

27. Passed on December 15, 1989, it came into force on January 1, 1990. For the text of the Act, see Bundesgesetzblatt I 1989 S 2198.

28. Kelly and Aturee, supra note 22, p. 152.

29. G. Schwartz, 1991, "Product Liability and Medical Malpractice in Comparative Context," in P. Huber and R. Litan, Eds. The Liability Maze, Washington, D.C.: Brookings, p. 49.

30. Decree 224 of May 24, 1988. Notc that decrees are frequently used when the Italian legislature is paralyzed, but that there is rarely conflict between the versions of a law promulgated by decree and those subsequently promulgated by the legislature.

31. This occurred with the 1964 decision of the highest court of appeals, the Corte di Cassazione, of May 25, 1964, no. 1270 in Foro Italiano, 1965, 1, 2098. Kelly and Attree, supra note 22, p. 296.

32. Ibid., P. 234

33. See discussion of a 1989 case of foodstuffs poisoning in G. Howells, 1993, Comparative Product Liability, Brookfield, MA: Dartmouth University Press, p. 151.

34. Rolf Magrell, Olaf Nillson, and Stefan Sandeun, 1988, "Sweden," in Warren Freedman, Ed. Proluct Liability: an International Manual of Practice, Dobbs Ferry, NY: Oceana, p. 16. 
35. Kelly and Attree, supra note 22, p. 334.

36. See Howells, supra note 33.

37. In the words of one commentator, the 1980 law "cannot be explained in terms of a political decision to rectify any social or economic wrong or resolve an particular legal problem stemming from products liability ... the law can rather be explained in terms of the legislator's awareness of the new developments in the advanced legal systems, and its realization that the law should adapt to the changes in the Israelis' socio-economic organization." Daniel Moe, "Israel," in Freedman, supra note 34 , p. 3.

38. A translation appears in Iloyds Product Liability International July 31, 1994, at 101.

39. J. Mark Ramseyer has shown the variety of collateral incentives that the long-ruling Liberal Democratic Party imposed on the Japanese Supreme Court. See Ramseyer and Frances Rosenbluth, 1993, Japan's Political Marketplace, Cambridge, MA: Harvard University Press, and also Ramseyer and Kric B. Rasmusen, "Judicial Independence in Civil Law Regimes: Econometrics from Japan," manuscript on file with authors.

40. The mean number of vetoes for the latter group was 1.3 , compared with 2.0 for the first two groups combined. The mean coalition duration was 7.18 , compared with 4.62 for the first two groups.

41. These separate courts began in France and have been adopted in most continental jurisdictions. H.B. Jacobini, 1991, An Introduction to Comparative Administrative Law, New York: Oceana.

42. J. Mark Ramseyer, "The Puzzling (In)dependence of Courts: A Comparative Approach," $23: 2$ Joumal of Legal Studies 721 (1994).

43. William Landes and Richard Posner, "The Independent Judiciary in an Interest Group Perspective," 18 Journal of Law and Economics 875 (1975).

44. Ramscyer, supra note 42.

45. We began by counting the total number of pages in the country's general air and water pollution statutes at the national level. We then took a 10-page sample and counted the number of words on each page. Next we multiplied the total number of pages by the average number of words in the 10-page sample to produce our estimates. To compensate for the different strucure of the Japanese language, we used a crude measure by which two characters are equivalent to one English word. Note that even with this adjustment, our estimate probably overstates the number of Englishlanguage equivalent words in the statute.

46. Another available figure, for which implementing regulations are not available, is the New Zealand Clean Air Act $(19,282$ words $)$.

47. Another country for which substatutory regulations were not available was Canada. The Canadian Environmental Protection Act, as recorded in Statutes of Canada (1993) Chap. C-15.3, totals 25,480 words, and covers subjects beyond air and water pollution. However, other elements of air and water pollution regulation are dealt with by unrelated statutes in Canada such as the Canada Shipping Act and the National Telecommunications Powers and Procedures Act.

48. An excellent discussion of envirommental regulation in Japan is found in Frank Upham, 1987, Law and Social Change in Postwar Japan, Cambridge, NY: Harvard Lniversity Press.

49. David Vogel, 1986, National Styles of Regulation, Ithaca, NY: Cornell University Press.

50. See J. Badaracco, 1985, Loading the Dice: A Five Country Study of Vinyl Chloride Regulation, Cambridge, MA: Harvard University Press.

51. Vogel, supra note 49 at 173.

52. Tommy Nillson, 1993, "Sweden," in M. Brealey, Ed. Environmental Liabilities and Regulation in Europe, The Hague: International Business Publishing Ltd, p. 433.

53. This regression only concerns subjective perceptions of discretion by comparative law experts. Alter eliciting their opinions, we explained the model to them. The typically expressed skepticism that such a simple model could work. Apparently, the comparative law experts should find the strength of the regression results to be counterintuitive.

54. This agreement is developed at greater length in R. Cooter and J. Drexl, "The Logic of Power in the Emerging European Constitution: Game Theory and the Division of Powers" 14 International Review of Law and Eromomics 307 (September 1994). 
55. The start year usually begins with 1945 or with the subsequent establishment of a new constitutional order. Occasionally, problems in gathering the data forced us to modify the original start date.

56. A coalition change only occurs when the party composition of the cabinet changes. A simple reshuffling of seats among cxisting coalition partners is not counted as a change.

57. Although Italy has had over 50 governments in the postwar period, some of these cabinets replaced earlier cabinets of exactly the same party composition. For purposes of our calculations we did not count such instances as a break in the coalition.

58. For the United States, the only changes in coalition occur when the Presidency changes hands. Hence the average duration is higher than the constitutionally mandated 4-year Presidential term. 